\title{
The Impact of Discount Rate and Price on Intertemporal Groundwater Models in Southwest Kansas
}

\author{
Mallory K. Vestal1 ${ }^{*}$, Bridget L. Guerrero' ${ }^{1}$, Bill B. Golden², Logan D. Harkey ${ }^{1}$ \\ ${ }^{1}$ Department of Agricultural Sciences, West Texas A\&M University, Canyon, TX, USA \\ ${ }^{2}$ Department of Agricultural Economics, Kansas State University, Manhattan, KS, USA \\ Email: *mvestal@wtamu.edu, bguerrero@wtamu.edu, bgolden@k-state.edu, lharkey@wtamu.edu
}

How to cite this paper: Vestal, M.K., Guerrero, B.L., Golden, B.B. and Harkey, L.D. (2017) The Impact of Discount Rate and Price on Intertemporal Groundwater Models in Southwest Kansas. Journal of Water Resource and Protection, 9, 745-759. https://doi.org/10.4236/jwarp.2017.97049

Received: April 5, 2017

Accepted: June 10, 2017

Published: June 13, 2017

Copyright $\odot 2017$ by authors and Scientific Research Publishing Inc. This work is licensed under the Creative Commons Attribution-NonCommercial International License (CC BY-NC 4.0). http://creativecommons.org/licenses/by-nc/4.0/

\begin{abstract}
Agriculture plays a vital role in the growth and development of the High Plains Region of the United States. With the development and adoption of irrigation technology, this region was transformed into one of the most agriculturally productive regions in the world [1]. The primary source of irrigation in this region is the Ogallala Aquifer. Currently, water from the aquifer is being used at a much faster rate than natural recharge can occur, resulting in a high rate of depletion from this finite resource. Depletion of scarce water resources will have a significant economic impact on the long-term sustainability of the region. The objective of this study is to evaluate the impact alternative prices and discount rates have on groundwater policy recommendations. Deterministic models of groundwater withdrawals were developed and used in order to analyze and evaluate the impact of high, average, and low crop prices in a status quo scenario as well as a policy scenario reducing irrigated acreage allocation. Furthermore, this study analyzes the effects and associated consequences of alternative discount rates on net and total revenue. As indicated by results of this study, alternative prices, costs, and discount rates utilized in a model have an effect on policy effectiveness.
\end{abstract}

\section{Keywords}

Acreage Reduction, Discount Rate, Irrigation, Ogallala Aquifer, Water Policy

\section{Introduction}

Agriculture has been a key factor in the overall evolution and expansion of the High Plains Region. The invention of affordable irrigation technology has aided in the transformation of the High Plains into a more fertile farming region in 
which a large number of crops are grown annually [1]. More than ninety percent of the groundwater pumped from the Ogallala Aquifer irrigates approximately one-fifth of all cropland in the United States [2]. The region produces corn, grain sorghum, soybeans, wheat, and alfalfa with irrigation drawn from the aquifer. In addition, a large number of concentrated animal feeding operations and meat processing facilities operate within the region. Approximately eighty percent of the nation's cattle on feed are located within the High Plains Region [3]. However, the increase in irrigated agriculture and irrigated acres as well as the low amounts of natural recharge are impacting the aquifer.

The depletion of the Ogallala Aquifer has significant implications for the High Plains Region as a whole. The continued decline in water availability from the aquifer has led to an increase interest in water conservation policies. These policies are designed to extend the life of the aquifer and sustain rural economies and associated agricultural enterprises [4]. Thus, the overall objective of this study is to evaluate groundwater policies in four Southwest Kansas counties. Specifically, this research analyzes how alternative discount rates applied to revenue and varied levels of crop prices can affect policy recommendations regarding the pumping of groundwater from the Ogallala Aquifer. Applying alternative discount rates to net and total revenue allows for a detailed examination of profits considering the difference in the value of receiving money now versus in the future. Various discount rates and price levels are applied to a status quo scenario as well as an acreage reduction scenario within the model. This is done to show how profit levels vary as prices fluctuate and the need to pump water increases and decreases throughout time.

\section{Study Area}

The focus of this study is on four counties in Southwest Kansas that are rich in agriculture, but have high groundwater depletion rates in comparison to low amounts of recharge. Finney, Grant, Hamilton, and Stevens counties account for the production of over 370,000 acres of corn, more than 195,000 acres of sorghum, andover 23,000 acres of soybeans [5] (Figure 1, Table 1). Approximately 2.2 million acres lie above the Ogallala Aquifer in these four counties alone (Table 2). The Ogallala Aquifer is a body of water which lies underneath parts of Texas, New Mexico, Oklahoma, Colorado, Kansas, Nebraska, Wyoming, and South Dakota, spanning roughly 174,000 square miles [6]. Under current pro-

Table 1. Production acreages by county ${ }^{\mathrm{a}}$.

\begin{tabular}{cccccc}
\hline County & $\begin{array}{c}\text { LEPA System } \\
\text { Acres }\end{array}$ & $\begin{array}{c}\text { Furrow Irrigation } \\
\text { Acres }\end{array}$ & $\begin{array}{c}\text { Dryland } \\
\text { Acres }\end{array}$ & $\begin{array}{c}\text { LEPA } \\
\text { Percentage }\end{array}$ & $\begin{array}{c}\text { Total } \\
\text { Irrigated Acres }\end{array}$ \\
\hline Finney & 189,924 & 53,947 & 188,642 & $77.9 \%$ & 243,872 \\
Grant & 97,308 & 24,761 & 89,665 & $79.7 \%$ & 122,069 \\
Hamilton & 21,989 & 14,868 & 182,735 & $59.7 \%$ & 36,857 \\
Stevens & 191,937 & 15,035 & 121,153 & $92.7 \%$ & 206,972 \\
\hline
\end{tabular}

a Source: The Water Information Management and Analysis System (WIMAS). 


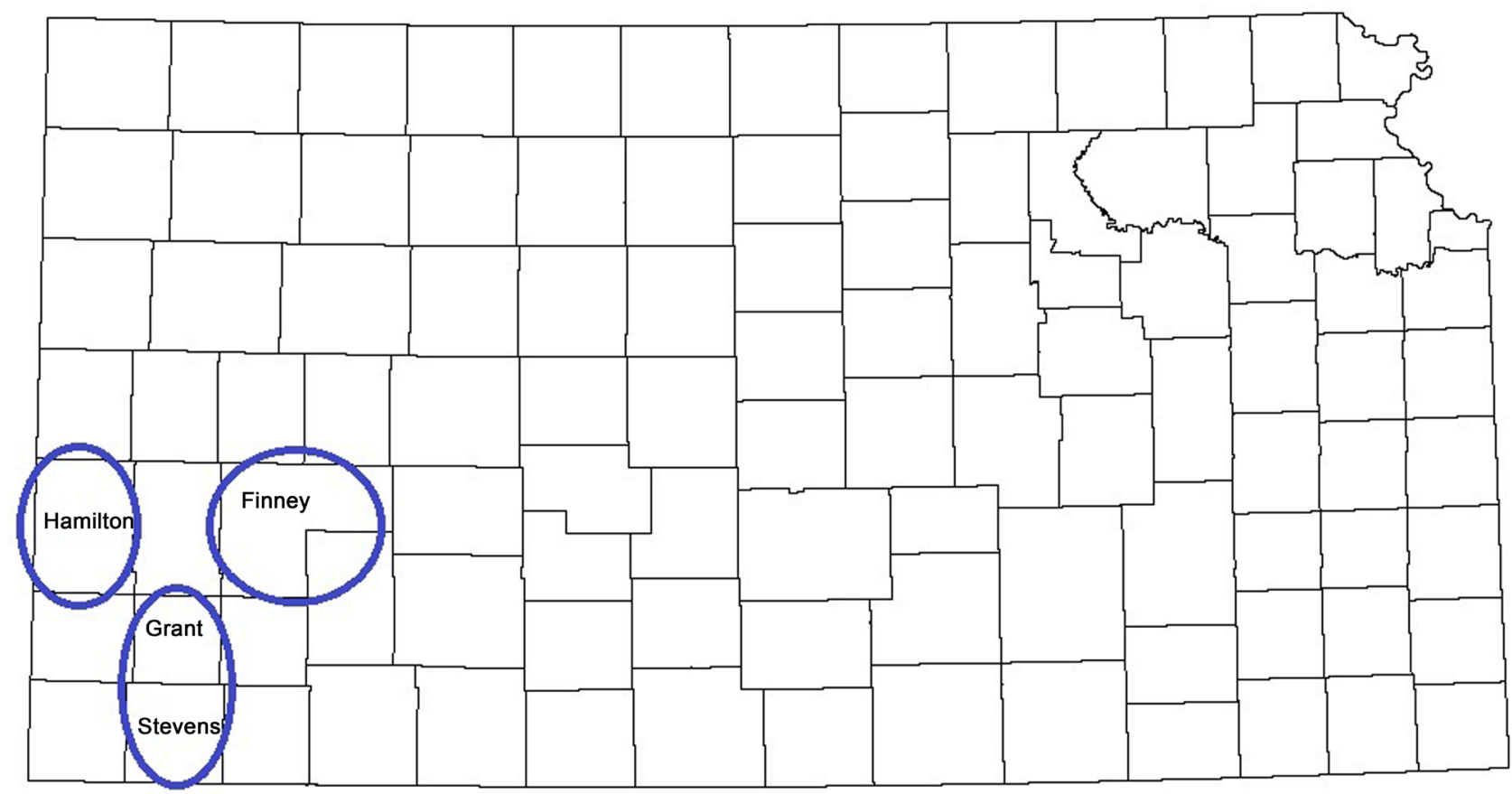

Figure 1. Southwest Kansas counties evaluated. Source: www.worldatlas.com.

Table 2. Acreages by county ${ }^{\mathrm{a}}$.

\begin{tabular}{ccc}
\hline County & Land Area Acres & Acres Overlying the Aquifer \\
\hline Finney & 830,808 & 739,419 \\
Grant & 368,115 & 368,115 \\
Hamilton & 640,047 & 608,044 \\
Stevens & 466,497 & 466,497 \\
Total & $2,305,047$ & $2,182,075$ \\
\hline
\end{tabular}

aSource: The Water Information Management and Analysis System (WIMAS).

duction practices, water table levels in the Ogallala decline at a rate from approximately six inches to several feet annually. This holds particularly true in the southernmost portions of the Ogallala, where natural recharge is small in comparison to other areas [6].

\section{Methodology}

The effect of crop price and discount rate of revenues generated from groundwater withdrawal were evaluated in this study using county-level deterministic models. Matrix Laboratory (MATLAB) [7] was used in this study to solve the optimization models formulated and to evaluate the profits accrued and the levels of water withdrawn from the Ogallala in each scenario. The framework for the model was originally developed by [8], and subsequently developed by [9] [10] [11] [12] and [13]. Most recently [14] utilized General Algebraic Modeling System within the non-linear dynamic optimization model. This model was then incorporated and solved in MATLAB. 
The model was utilized to generate outcomes for two alternative scenarios. The first policy, a status quo scenario, did not incorporate changes in current practices. This scenario was included to model outcome should irrigation continue at current rates without regulation. The four crops analyzed in the model were irrigated corn, irrigated grain sorghum, irrigated soybeans, and dryland alternatives for the aforementioned three crops.

The second policy, factored in a 10\% reduction of irrigated acreage for Finney, Grant, Hamilton, and Stevens counties. Under both the status quo and the acreage reduction policy, alternative scenarios were run to allow for years of high, average, and low prices for each crop. This was done in an effort to discern how the output would change dependent on crop prices and yields. Furthermore, various discount rates were applied to revenues obtained under both the status quo scenario and the acreage reduction scenario. This step was taken in order to evaluate how the discount rate ultimately affects the model's results and consequently the choice of groundwater conservation policy. The discount rates applied to net and total revenues under both the status quo and the acreage reduction scenario were $5 \%, 2.5 \%, 0 \%,-2.5 \%$, and $-5 \%$. The application of discount rates converts future revenue to present dollars. Typically, a positive discount rate is used, indicating that present consumption is valued more than future consumption. However, alternative discount rates should be considered when analyzing water use in order to reflect differences in stakeholder goals for water conservation. A $0 \%$ discount rate means current and future consumption are valued equally, while a negative discount rate, such as $-2.5 \%$ or $-5 \%$, reflects that future consumption is worth more.

While this study compares a status quo scenario to a groundwater conservation scenario, the purpose is not to justify one over the other. Instead, the focus of this study is on how alternative prices and discount rates impact the choice of policy. Discounting converts future revenue to present dollars. Typically a positive discount rate is used. This is indicative of present consumption holding higher value than future consumption. However, alternative discount rates should be considered when analyzing water use to reflect differences in stakeholder goals for water conservation. This information is relevant given the high prevalence of irrigated agriculture in the region. This is evident based upon the large number of irrigated acres for the counties in study (Table 1).

\section{Model Specification}

The focus of this study is the examination of groundwater policy, and the impact alternative prices and discount rates have on policy recommendations. The primary goal of the county-level, optimization model is to maximize net revenue accrued through irrigated crop production. This model assumes a profit maximizing producer will choose crop acreage allocation and crop-water application rates in such a manner as to maximize annual profits. The use of an optimization objective function based on maximizing producer net profits is consistent with past literature. Implicitly, this assumes that groundwater management 
should be based on what is best for the agricultural producer. The models were run over a fifty-year planning horizon for each county.

\section{Data}

Three irrigated crops were analyzed within this study. Crop 1 (C1) was irrigated corn, irrigated grain sorghum was crop 2 (C2), and crop 3 (C3) was irrigated soybeans. Of the three crops analyzed in the study, corn is the most prominent crop grown in each of the counties, with both sorghum and soybeans playing much smaller roles. Access to the aquifer helps account for the production of more than 370,000 acres of corn, 195,000 acres of sorghum, and 23,000 acres of soybeans [5]. Crop 4 (C4) was used in the model as a representation of the overall dryland production of $\mathrm{C} 1, \mathrm{C} 2$, and C3. A variety of different crops are actually grown in each county; however, only irrigated corn, irrigated grain sorghum, and irrigated soybeans were evaluated in this model. To do this, a normalized percentage was calculated for these three crops. This was done by calculating the percentage of overall production $\mathrm{C} 1, \mathrm{C} 2$, and C 3 make up in acres. This percentage was then taken and applied to the total amount of available acres in each county in order to analyze how production would look if only C1, C2, and C3 were grown. The amount of irrigated acres allotted to each crop was assigned based on these values.

Specific data was compiled for each county within the study region. The county specific data included averages of planted irrigated acreages of cotton, grain sorghum, soybeans, and dryland production. Operating costs were also collected by crop, including variable expenses such as irrigation fuel, seed, fertilizer, and harvesting and hauling. Crop prices and costs used in this analysis represent average 2011 through 2015 Cost-Return Budgets published by the Kansas State University Agricultural Experiment Station and Cooperative Extension Service [15]. The budgets were modified to reflect long-run average returns to land, management, and equipment. As yield changes, fertilizer, repairs and maintenance, and fuel expenses were adjusted appropriately. For example, overall repair and maintenance costs to equipment decrease in years of low yield because farmers are not prompted to work their machines as hard as in years of high yield. Likewise, fuel expenses decrease as less total fuel is needed to irrigate and harvest a low yield crop in comparison to a high yield crop.

Hydrologic data collected included the area of each county overlying the aquifer, basin surface area, depth to water, saturated thickness, hydraulic conductivity, and specific yield. The amount of natural recharge in the Ogallala is not known, and most estimates are considered controversial at best. For the purposes of this study, total annual recharge was left at zero feet and therefore not included in the parameters of the model. The saturated thickness, aquifer recharge, hydraulic conductivity, specific yield, and average decline in saturated thickness data was obtained from The Kansas Geological Survey High Plains Aquifer Section-Level Database [16]. The hydrologic data incorporated in this study is found in Table 3. The Water Information Management and Analysis 
Table 3. County hydrologic parameters ${ }^{\mathrm{a}}$.

\begin{tabular}{cccccccc}
\hline County & $\begin{array}{c}\text { Recharge } \\
\text { (in/ac) }\end{array}$ & $\begin{array}{c}\text { Pump } \\
\text { Lift } \\
(\text { Feet })\end{array}$ & $\begin{array}{c}\text { Saturated } \\
\text { Thickness } \\
(\text { Feet })\end{array}$ & $\begin{array}{c}\text { Well } \\
\text { Yield } \\
(\mathrm{GPM})\end{array}$ & $\begin{array}{c}\text { Acres } \\
\text { Per } \\
\text { Well }\end{array}$ & $\begin{array}{c}\text { Specific } \\
\text { Yield } \\
\left(\mathrm{ft}^{3}\right)\end{array}$ & $\begin{array}{c}\text { Hydraulic } \\
\text { Conductivity } \\
(\mathrm{ft} / \text { day })\end{array}$ \\
\hline Finney & 0 & 121 & 183 & 1000 & 126 & 0.159 & 80.03 \\
Grant & 0 & 233 & 199 & 1000 & 126 & 0.133 & 55.36 \\
Hamilton & 0 & 173 & 72 & 585 & 126 & 0.136 & 48.89 \\
Stevens & 0 & 185 & 322 & 1000 & 126 & 0.156 & 65.73 \\
\hline
\end{tabular}

${ }^{a}$ Source: The Kansas Geological Survey High Plains Aquifer Section-Level Database.

System (WIMAS) [5] provided data on water rights, water use, irrigated crop mix, and type of irrigation technology used.

\section{Results}

The results of this study are indicative of a rapidly depleting aquifer, declining levels of saturated thickness, and ever increasing difficulty of earning profit in the farming industry. A detailed explanation of results are presented for Finney and Stevens counties, and a generalization of the findings are presented for Grant and Hamilton counties within this section. Figures of saturated thickness levels, total water use, and total revenue are included for Finney and Stevens counties. In each figure, saturated thickness, total water use, and revenue generated under high, average, and low crop prices for both the status quo scenario (SQ) as well as the acreage reduction scenario (AR) are presented over the fifty year study horizon under a $0 \%$ discount rate.

The relationship between discount rate $(5 \%, 2.5 \%, 0 \%,-2.5 \%$, and $-5 \%)$ and net revenue is presented for Finney and Stevens counties under low, average, and high crop prices in Table 4 and Table 5. These discount rates are evaluated for revenues accrued under both the status quo scenario as well as the acreage reduction scenario. The percent change from one scenario to the other is presented in the last column of each table.

\subsection{Finney County}

Finney County is the easternmost county in this study. Finney has over 830,000 acres of land area and approximately 739,000 acres overlying the Ogallala Aquifer, making it the largest county in study. Despite its size, saturated thickness in Finney County steadily declines under each scenario and price analyzed within the model. However, the acreage reduction scenario does allow for slower depletion of the Ogallala. Overall, the acreage reduction scenario under low price years allows for the slowest depletion rates. The aquifer is shown to decline by approximately 100 feet over the next fifty years, resulting in about half as much water being available fifty years from now as is available today (Figure 2). Notice that relative to the corresponding status quo scenario, all acreage reduction scenarios have more saturated thickness at the end of the fifty year modeling horizon. This implies that the acreage reduction scenario conserves groundwater. 
Table 4. Discount rate analysis for Finney County.

\begin{tabular}{ccccc}
\hline $\begin{array}{c}\text { Discount } \\
\text { Rate }\end{array}$ & Price & $\begin{array}{c}\text { Revenue Status Quo } \\
\text { Scenario }\end{array}$ & $\begin{array}{c}\text { Revenue Acreage Reduction } \\
\text { Scenario }\end{array}$ & $\begin{array}{c}\text { Percent } \\
\text { Change }\end{array}$ \\
\hline $5.0 \%$ & Low & $\$ 1,014,808,037$ & $\$ 982,225,204$ & $3.21 \%$ \\
$5.0 \%$ & Average & $\$ 1,862,313,301$ & $\$ 1,776,008,394$ & $4.63 \%$ \\
$5.0 \%$ & High & $\$ 2,732,866,346$ & $\$ 2,582,668,126$ & $5.50 \%$ \\
$2.5 \%$ & Low & $\$ 1,549,494,332$ & $\$ 1,505,265,922$ & $2.85 \%$ \\
$2.5 \%$ & Average & $\$ 2,795,430,853$ & $\$ 2,689,293,483$ & $3.80 \%$ \\
$2.5 \%$ & High & $\$ 4,101,451,729$ & $\$ 3,906,827,244$ & $4.75 \%$ \\
$0.0 \%$ & Low & $\$ 2,675,118,457$ & $\$ 2,608,462,996$ & $2.49 \%$ \\
$0.0 \%$ & Average & $\$ 4,701,200,146$ & $\$ 4,574,727,774$ & $2.69 \%$ \\
$0.0 \%$ & High & $\$ 6,894,295,589$ & $\$ 6,635,213,229$ & $3.76 \%$ \\
$-2.5 \%$ & Low & $\$ 5,334,510,354$ & $\$ 5,217,122,348$ & $2.20 \%$ \\
$-2.5 \%$ & Average & $\$ 9,058,104,485$ & $\$ 8,928,970,125$ & $1.43 \%$ \\
$-2.5 \%$ & High & $\$ 13,272,949,046$ & $\$ 12,923,110,955$ & $2.64 \%$ \\
$-5.0 \%$ & Low & $\$ 12,343,142,078$ & $\$ 12,092,015,470$ & $2.03 \%$ \\
$-5.0 \%$ & Average & $\$ 20,179,262,161$ & $\$ 20,138,196,899$ & $0.20 \%$ \\
$-5.0 \%$ & High & $\$ 29,537,862,034$ & $\$ 29,077,677,205$ & $1.56 \%$ \\
\hline & & & & \\
\hline
\end{tabular}

Table 5. Discount rate analysis for Stevens County.

\begin{tabular}{ccccc}
\hline $\begin{array}{c}\text { Discount } \\
\text { Rate }\end{array}$ & Price & $\begin{array}{c}\text { Revenue Status Quo } \\
\text { Scenario }\end{array}$ & $\begin{array}{c}\text { Revenue Acreage Reduction } \\
\text { Scenario }\end{array}$ & $\begin{array}{c}\text { Percent } \\
\text { Change }\end{array}$ \\
\hline $5.0 \%$ & Low & $\$ 679,223,368$ & $\$ 665,075,497$ & $2.08 \%$ \\
$5.0 \%$ & Average & $\$ 1,515,639,583$ & $\$ 1,430,303,839$ & $5.63 \%$ \\
$5.0 \%$ & High & $\$ 2,354,082,483$ & $\$ 2,197,270,619$ & $6.66 \%$ \\
$2.5 \%$ & Low & $\$ 1,034,881,685$ & $\$ 1,016,845,357$ & $1.74 \%$ \\
$2.5 \%$ & Average & $\$ 2,333,515,727$ & $\$ 2,205,036,436$ & $5.51 \%$ \\
$2.5 \%$ & High & $\$ 3,635,985,123$ & $\$ 3,396,499,292$ & $6.59 \%$ \\
$0.0 \%$ & Low & $\$ 1,782,330,102$ & $\$ 1,758,685,652$ & $1.33 \%$ \\
$0.0 \%$ & Average & $\$ 4,069,705,557$ & $\$ 3,851,719,244$ & $5.36 \%$ \\
$0.0 \%$ & High & $\$ 6,365,239,269$ & $\$ 5,951,675,535$ & $6.50 \%$ \\
$-2.5 \%$ & Low & $\$ 3,543,254,144$ & $\$ 3,512,022,656$ & $0.88 \%$ \\
$-2.5 \%$ & Average & $\$ 8,197,926,262$ & $\$ 7,771,643,546$ & $5.20 \%$ \\
$-2.5 \%$ & High & $\$ 12,872,072,627$ & $\$ 12,047,712,694$ & $6.40 \%$ \\
$-5.0 \%$ & Low & $\$ 8,166,138,722$ & $\$ 8,127,592,773$ & $0.47 \%$ \\
$-5.0 \%$ & Average & $\$ 19,120,194,144$ & $\$ 18,152,894,765$ & $5.06 \%$ \\
$-5.0 \%$ & High & $\$ 30,125,943,077$ & $\$ 28,221,692,996$ & $6.32 \%$ \\
\hline
\end{tabular}




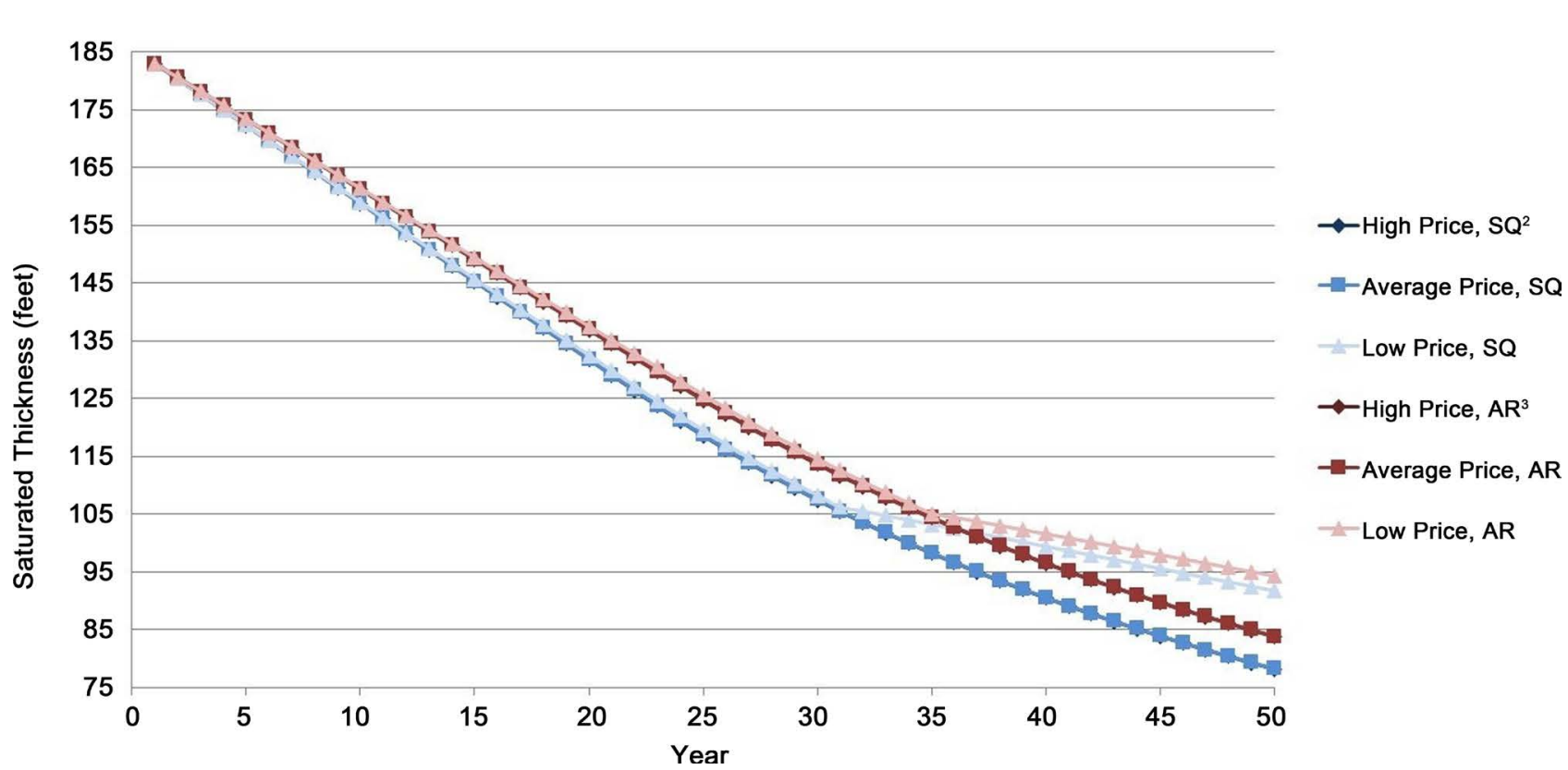

Figure 2. Finney County saturated thickness ${ }^{1} .{ }^{1}$ Results obtained under a 0\% discount rate; ${ }^{2}$ SQ: Status Quo Scenario; ${ }^{3} \mathrm{AR}$ : Acreage Reduction Scenario.

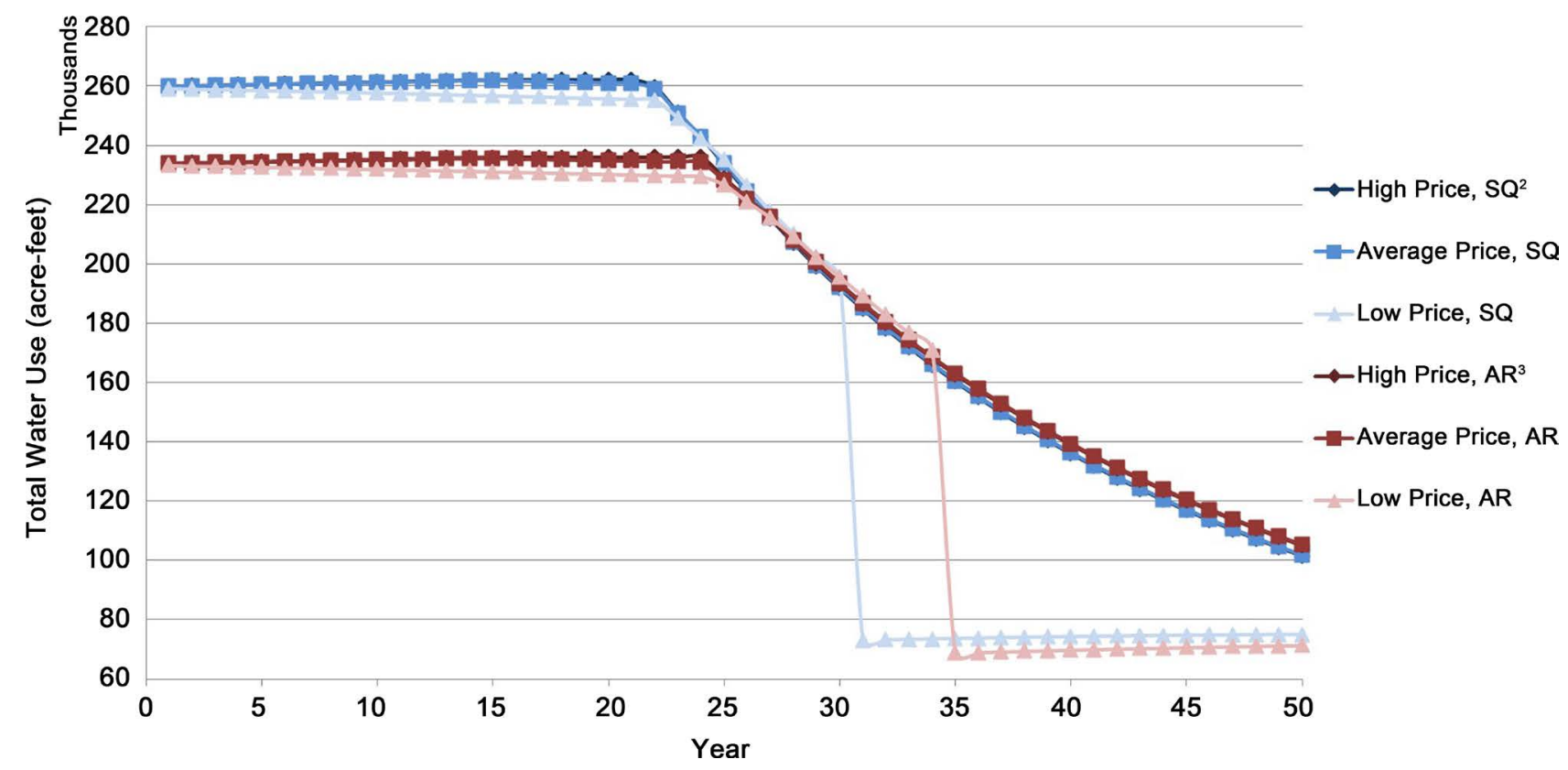

Figure 3. Finney County total water use ${ }^{1} .{ }^{1}$ Results obtained under a 0\% discount rate; ${ }^{2} \mathrm{SQ}$ : tatus Quo Scenario; ${ }^{3} \mathrm{AR}$ : Acreage Reduction Scenario.

Reference [17] suggest that an objective analysis should place monetary value on the conserved groundwater. Valuing the conserved groundwater goes beyond the scope of this paper and requires future research.

With 1811 wells located within its borders, Finney County has over two times the number of wells as any other county in this study [5]. Total water use for Finney County will decline over the next fifty years due to increased difficulty of extracting water resulting from the ever dwindling water table. The two sharp drops in water use shown in Figure 3, are indicative of producers switching to 


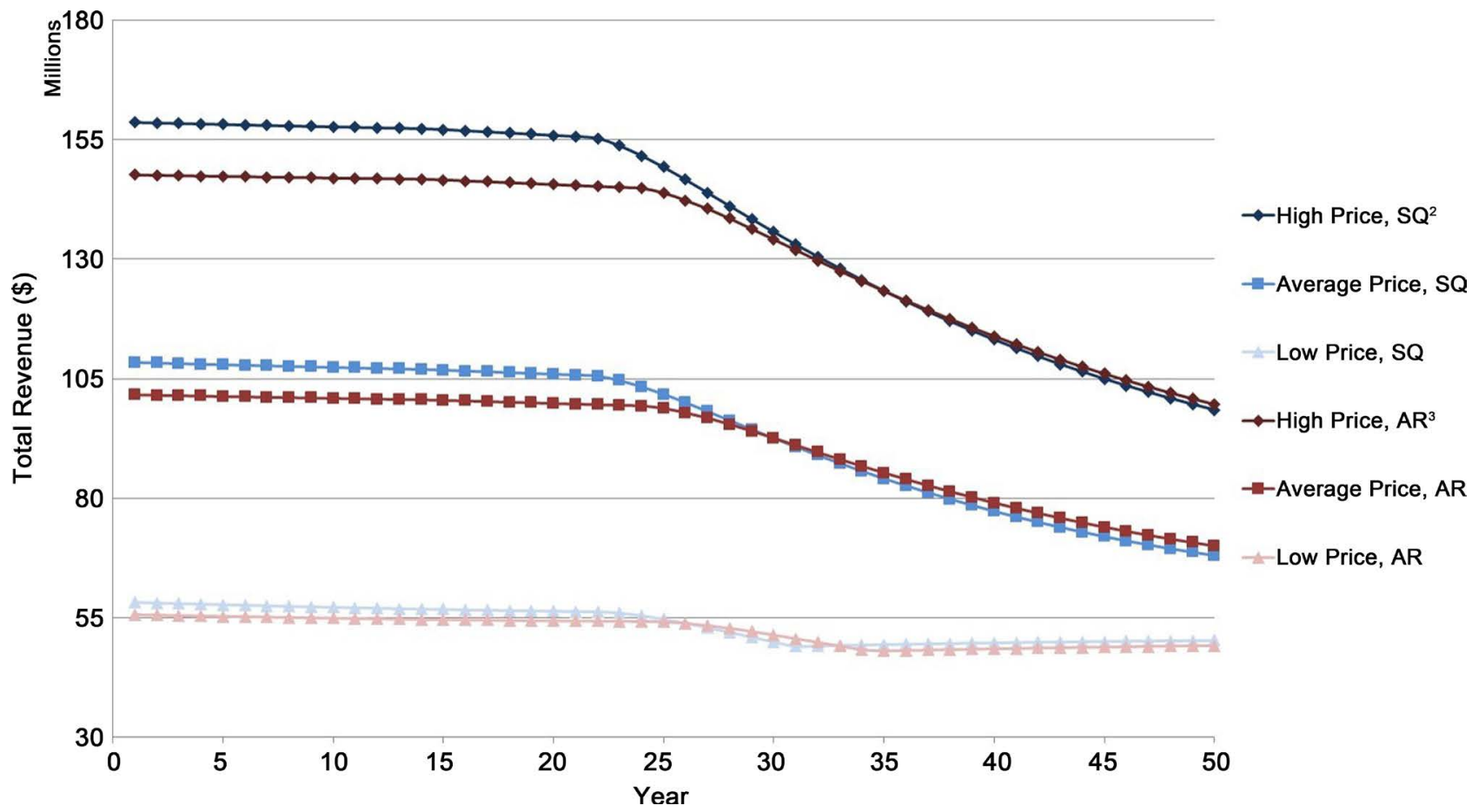

Figure 4. Finney County total revenue ${ }^{1} .{ }^{1}$ Results obtained under a $0 \%$ discount rate; ${ }^{2}$ SQ: Status Quo Scenario; ${ }^{3}$ AR: Acreage Reduction Scenario.

dryland production, because the water table shrinks to the extent in which it is no longer economically feasible to irrigate when crop prices are low. With low crop prices, it is estimated this change would occur in thirty years under the status quo scenario and in thirty-five years acreage reduction scenario.

An analysis of net revenue earned under each scenario with alternative discount rates is presented in Table 4 . The percent change between status quo revenue and acreage reduction revenue is largest under a $5 \%$ discount rate and high price scenario, and smallest under a $-5 \%$ discount rate and average price scenario. Discount rate is important as it implies preferences of producers. Positive discount rates are indicative of a producer who is concerned with short-term profits, while negative discount rates imply a preference of long-term profits. Subsequently, those with a negative discount rate are concerned with acquiring profits in the future, as the water table dwindles and irrigation becomes increasingly costly.

\subsection{Stevens County}

Stevens County has the largest level of saturated thickness out of the four counties. Levels of saturated thickness decline at a constant rate throughout the fifty year study period as shown in Figure 5. An acreage reduction scenario preserves about ten additional feet of saturated thickness in comparison to status quo. Overall, saturated thickness declines from 322 feet in year one to between 208 feet and 219 feet by the end of the study horizon.

Acreage reduction and status quo scenarios are practically mirror images of each other for total water use in Stevens County (Figure 6). As expected, high 


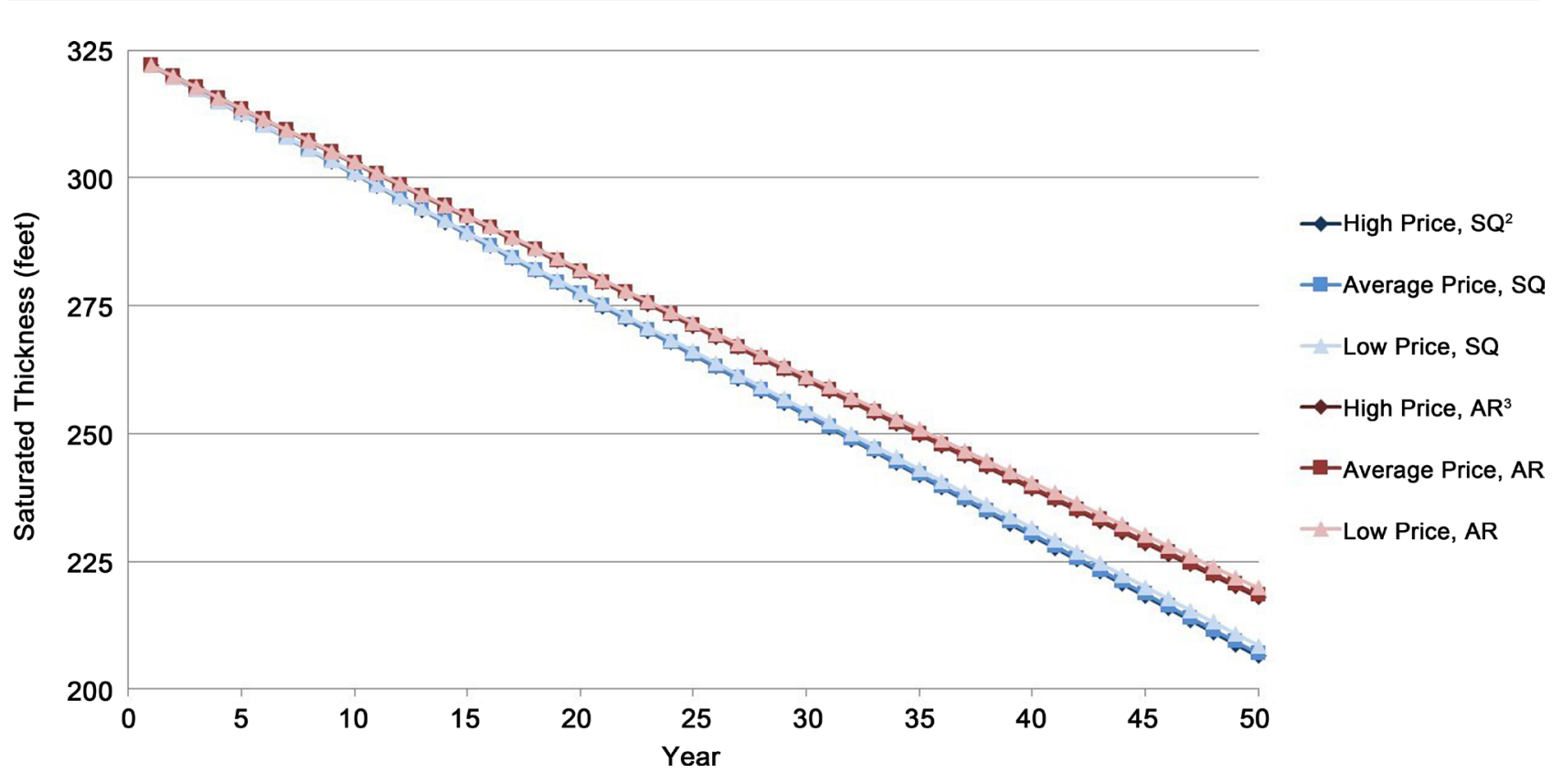

Figure 5. Stevens County saturated thickness ${ }^{1} .{ }^{1}$ Results obtained under a $0 \%$ discount rate; ${ }^{2}$ SQ: Status Quo Scenario; ${ }^{3} \mathrm{AR}$ : Acreage Reduction Scenario.

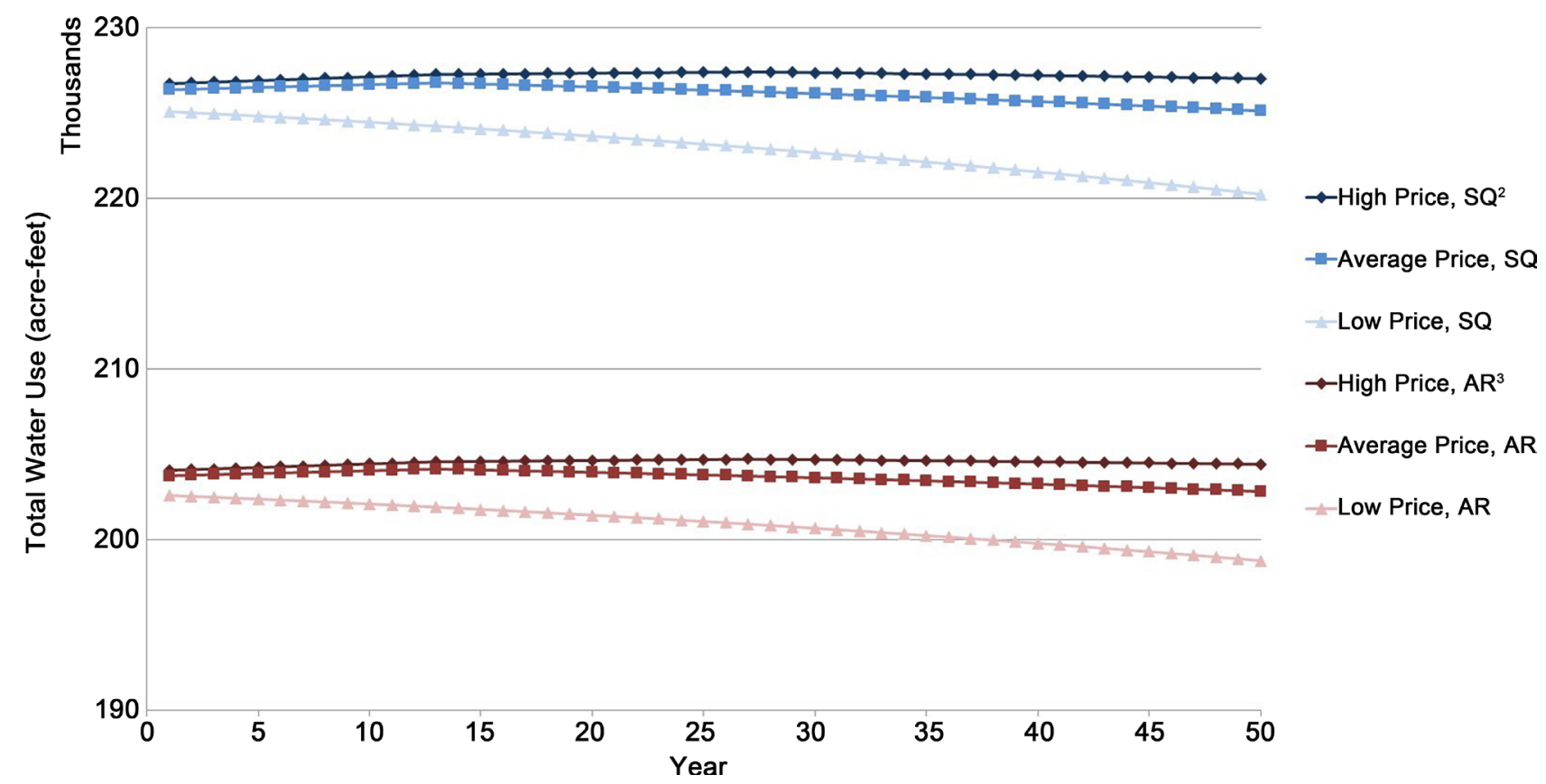

Figure 6. Stevens County total water use ${ }^{1} .{ }^{1}$ Results obtained under a $0 \%$ discount rate; ${ }^{2}$ SQ: Status Quo Scenario; ${ }^{3}$ AR: Acreage Reduction Scenario.

crop prices trigger the most water use, while low prices result in less depletion. Water rates are very similar under each scenario, with slightly less used under an acreage reduction policy. This can be attributed to the large amount of water available for pumping in Stevens County.

Due to the large amount of water available for irrigation, trends are somewhat different when compared to those in Finney, Grant, and Hamilton counties. When no acreage constraint is present, revenues are higher than the revenues 


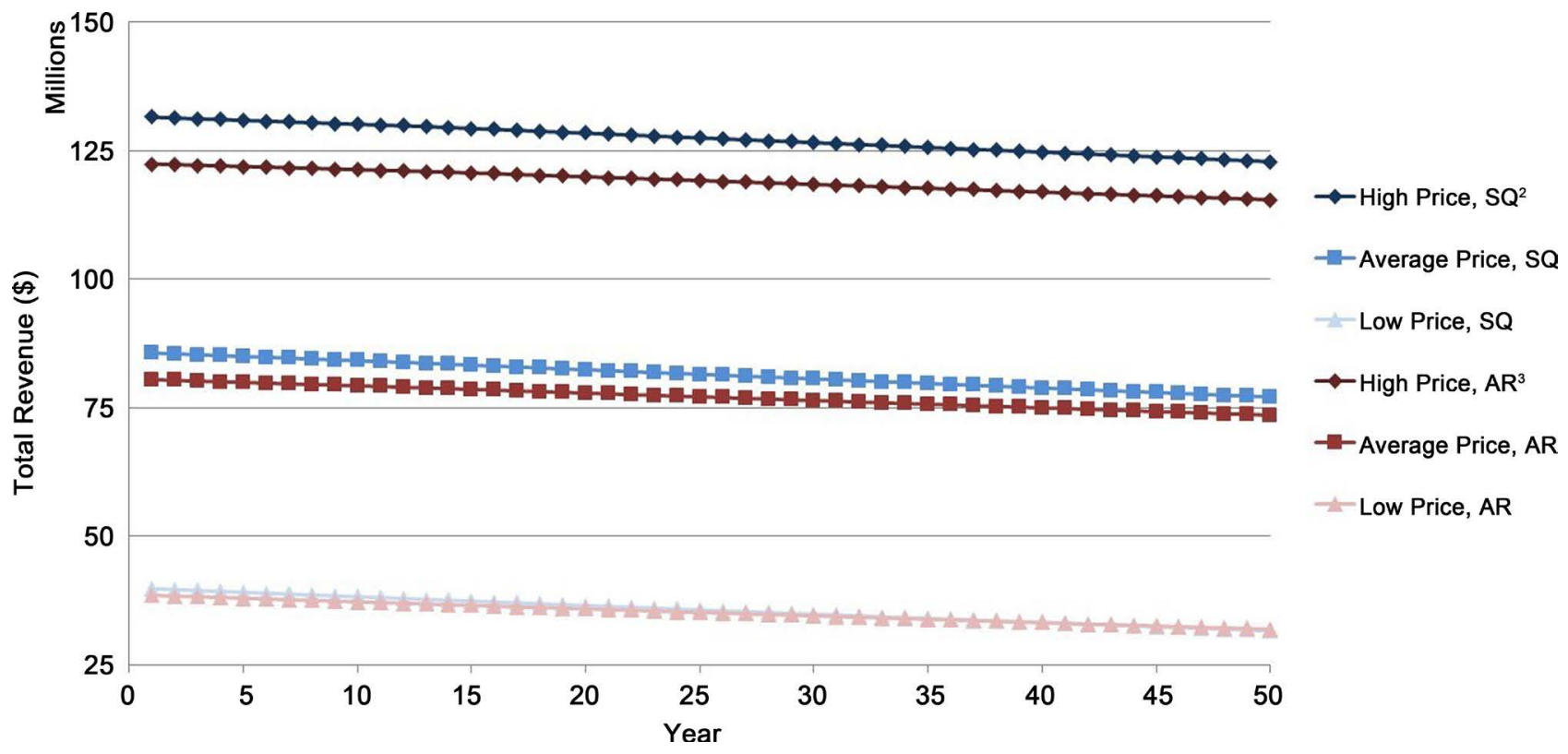

Figure 7. Stevens County total revenue ${ }^{1}{ }^{1}$ Results obtained under a $0 \%$ discount rate; ${ }^{2}$ SQ: Status Quo Scenario; ${ }^{3}$ AR: Acreage Reduction Scenario.

generated with an acreage reduction policy under both high and average crop prices. However, when faced with low crop prices, revenues received under the acreage reduction scenario begin to catch up to those received from the status quo scenario as shown in Figure 7. Although this trend is not portrayed in the graph for average and high prices, the same would hold true if the graph were extended to show additional years on the $\mathrm{x}$-axis as water levels continually decline.

In Stevens County, the percent change in revenues received under each scenario are smallest under low prices and largest under high prices (Table 5). Under an acreage reduction policy, producer's revenue is more dramatically impacted under average and high crop prices as compared to low crop prices, regardless of discount rate. When faced with low prices, revenue is not impacted to such a high degree as irrigation would be limited. However, producers with a positive discount rate would face a $2.08 \%$ reduction in revenue as compared to those facing a negative discount rate, who would only face a decrease of $0.47 \%$ in revenue.

\subsection{Hamilton County}

Conversely, Hamilton County has the smallest amount of saturated thickness of all counties in the study with a beginning depth of about 73 feet. Due to the lack of saturated thickness, the future for irrigated agriculture is dim. Water use is predicted to remain fairly constant under each scenario for ten years, followed by a rapidly decline in overall water use. This is indicative of the lack of water available for pumping. When faced with low crop prices, producers implement dryland production practices and total water use will decline sharply as a result. As a whole, the percent changes in revenue between the two scenarios is less due 
to the small amount of water available and the subsequent pumping limitations.

\subsection{Grant County}

The saturated thickness of Grant County declines at a constant rate under both the acreage reduction scenario and the status quo scenario; however, the acreage reduction scenario in shown to preserve more water throughout the fifty year study. In comparison, the acreage reduction scenario leaves approximately 70 feet of saturated thickness in the aquifer in year fifty. This additional fifteen feet of saturated thickness could prove vital for acquiring profits in years exceeding the fifty year study horizon. Total revenue is initially higher under the status quo scenario for each price category, however the acreage reduction policy will become more profitable between forty and fifty years as the ability to irrigate crops in Grant County is prolonged therefore resulting in greater revenues than those generated by a depleted aquifer and dryland farming.

When analyzing net revenue under the status quo and acreage reduction scenario, it is evident that an absence of reduction in irrigated acreage will yield more total revenue throughout the study than an application of a mandatory irrigated acreage reduction. High prices in combination with a $5 \%$ and $2.5 \%$ discount rate, will generate the largest percent change in revenue. The smallest percent change in revenue results from the combination of low crop prices and a negative discount rate.

\section{Conclusions}

The objective of evaluating how discount rate and price impact the recommendation of groundwater policy has a related, underlying question, "Should we choose groundwater policies with aquifer conservation in mind?" A policy reducing irrigated acreage by ten percent would reduce total water used in all four counties; however, a larger, more sustained water reduction is present in counties with a large level of saturated thickness. For example, Finney County, with its high level of saturated thickness, will save more water by implementing a ten percent reduction in irrigated acreage than would Hamilton County with its much lower level of saturated thickness. Less saturated thickness results in less water saving ability; therefore a policy of acreage reduction is most likely beneficial in counties possessing at least normal amounts of saturated thickness such as Finney, Grant, and Stevens counties, and less effective in counties with low amounts of saturated thickness such as Hamilton.

Production decisions are impacted by price. In Finney County, under low prices, producers are forced to convert to dryland as it becomes no longer economically feasible to irrigate crops and incur subsequent irrigation costs only to receive low prices for these crops upon harvest. Higher prices incentivize producers to use more water to maximize yield and subsequent profit. However, results indicate little difference in water use when comparing high and average prices, indicating well capacity is the limiting factor. Prices have a large impact on projected producer revenue. High prices help producers justify utilizing any 
means necessary to pursue high yields and high returns. However, low prices have a negative impact upon the willingness of producers to spend money which will subsequently affect purchases with businesses located in the regional economy.

As discussed previously, discounting converts future revenue into present dollars. Typically a positive discount rate is used, indicating that present consumption is valued more than future consumption. However, alternative discount rates should be considered when analyzing water use to reflect differences in stakeholder goals for water conservation. A $0 \%$ discount rate means current and future consumption are valued equally, while a negative discount rate, such as $-2.5 \%$ or $-5 \%$, reflects that future consumption is worth more. The producer who values current consumption would be impacted to a greater degree by the policy than the producer valuing future consumption, regardless of price present in the market.

In each of the four counties, the values of revenues accrued rise sharply as the discount rate becomes increasingly negative. This is indicative of future profits becoming increasingly difficult to obtain with a dwindling aquifer and increasing costs of pumping water for irrigation purposes. The acreage reduction scenario allows for revenue to remain more constant over the fifty year study period than does the status quo scenario (Figure 4 and Figure 7 ). This is due to the fact that implementing an acreage reduction policy of ten percent each year will allow for saturated thickness levels to remain deep enough to justify the use of irrigation pumping for more years than does the status quo scenario. The acreage reduction policy would help preserve the Ogallala as a whole for future generations.

While this analysis compares a status quo scenario to a groundwater conservation scenario, the purpose was not to justify one over the other. Instead the focus was on alternative prices and discount rates. The use of alternative prices does not have as large of an effect on results as the selection of a discount rate because of the large variation in net revenues which occur under alternative discount rates.

Shortcomings exist with every study. In order to focus on prices and discount rates, the model was somewhat simplified. As an example, technologic growth in crop yields was not included. Reference [18] illustrated that a groundwater conservation policy provides significant benefits when technologic growth in crop yields was included in the model. This study, much like [18], bases decisions largely on loss in producer income to assess the overall cost of implementing the conservation strategy analyzed. Furthermore, yields stay the same throughout the model as static yield growth is not assumed for any year. This helps keep everything on a comparable basis within the study. Crop prices, a key input parameter, is also held constant within the study horizon. These limitations, as with any model are accompanied with a level of subsequent error. The purpose of the study was not to generate completely accurate results, but rather to compare policy effectiveness across counties which differ in access and availability of 
irrigation resources.

While the implementation of the irrigated acreage reduction scenario was compared to a status quo scenario, this research does not attempt to place a monetary value on the water conserved by policy implementation. Furthermore, the cost must be weighed against the benefit of generating water savings. To accomplish this, a 'price tag' needs to be given to the conserved water [17] If a price tag was developed for the conserved water, this detail would allow for further and more detailed research on water policy analysis.

The results of the study completed here are not only expected to help frame future policy analysis, but also to provide a resource for policy makers as they continue to evaluate and implement policy preservation recommendations for the economic viability and sustainability of the Ogallala Aquifer. The policy comparison lends aid to policy makers as they determine the most effective strategy to conserve water while maintaining the economic viability of the resource and the region which is heavily dependent upon it.

\section{Acknowledgements}

This research was supported in part by the Ogallala Aquifer Program, a consortium of the USDA Agricultural Research Service, Kansas State University, Texas A\&M AgriLife Research, Texas A\&MAgriLife Extension Service, Texas Tech University, and West Texas A\&M University. A portion of funding for this research was provided by USDA to Project No. 2016-68007-25066, through the National Institute for Food and Agriculture's Agriculture and Food Research Initiative, Water for Agriculture Challenge Area. Project website:

http://www.ogallalawater.org/.

\section{References}

[1] Peterson, J.M., Marsh, T.L. and Williams, J.R. (2003) Conserving the Ogallala Aquifer: Efficiency, Equity, and Moral Motives. Choices (First Quarter), 15-18.

[2] Guru, M.V. and Horne, J.E. (2000) The Ogallala Aquifer. The Kerr Center for Sustainable Agriculture, Inc., Poteau, Oklahoma.

[3] USDA. United States Department of Agriculture. Cattle on Feed Report. 22 January, 2016.

http://usda.mannlib.cornell.edu/usda/nass/CattOnFe//2010s/2016/CattOnFe-01-222016.pdf

[4] Almas, L.K., Guerrero, B.L., Lust, D.G., Fatima, H., Tewari, R. and Taylor, R. (2017) Extending the Economic Life of the Ogallala Aquifer with Water Conservation Policies in the Texas Panhandle. Journal of water Resource and Protection, 9, 255-270.

[5] The Water Information Management and Analysis System (WIMAS). Maintained by the Kansas Department of Agriculture, Division of Water Resources. http://hercules.kgs.ku.edu/geohydro/wimas/index.cfm

[6] Torell, A.L., Libbin, J.D. and Miller, M.D. (1990) The Market Value of Water in the Ogallala Aquifer. Land Economics, 66, 163-175. https://doi.org/10.2307/3146366

[7] MATLAB. The MathWorks, Inc. R2015b (8.6.267246). 64-bit (Win 64). Purchased 20 August 2015. License Number: 1097494.

[8] Feng, Y. (1992) Optimal Intertemporal Allocation of Ground Water for Irrigation 
in the Texas High Plains. Ph.D. Dissertation, Texas Tech University, Lubbock, Texas.

[9] Arabiyat, T.S. (1998) Agricultural Sustainability in the Texas High Plains: The Role of Advanced Irrigation Technology and Biotechnology. M.S. Thesis, Texas Tech University, Lubbock, Texas.

[10] Terrell, B. (1998) Economic Impacts of the Depletion of the Ogallala Aquifer: An Application to the Texas High Plains. M.S. Thesis, Texas Tech University, Lubbock, Texas.

[11] Johnson, J.W. (2003) Regional Policy Alternatives in Response to Depletion of the Ogallala Aquifer. Ph.D. Dissertation, Texas Tech University, Lubbock, Texas.

[12] Das, B. (2004) Towards a Comprehensive Regional Water Policy Model for the Texas High Plains. Ph.D. Dissertation, Texas Tech University, Lubbock, Texas.

[13] Wheeler, E. (2005) Policy Alternatives for the Ogallala Aquifer: Economic and Hydrologic Implications. M.S. Thesis, Texas Tech University, Lubbock, Texas.

[14] Wheeler, E. (2008) Water Conservation Reserve Program Alternatives for the Southern Ogallala Aquifer. Ph.D. Dissertation, Texas Tech University, Lubbock, Texas.

[15] The Kansas State University Agricultural Experiment Station and Cooperative Extension Service. http://www.agmanager.info/farmmgt/fmg/irrigated/default.asp

[16] The Kansas Geological Survey High Plains Aquifer Section-Level Database. http://www.kgs.ku.edu/Magellan/WaterLevels/index.html

[17] Golden, B. and Johnson, J. (2013) Potential Economic Impacts of Water-Use Changes in Southwest Kansas. Journal of Natural Resources Policy Research, 5, 129 145. https://doi.org/10.1080/19390459.2013.811855

[18] Amosson, S., Almas, L., Golden, B., Guerrero, B., Johnson, J., Taylor, R. and Wheeler-Cook, E. (2009) Economic Impacts of Selected Water Conservation Policies in the Ogallala Aquifer. Report, Ogallala Aquifer Program.

Scientific Research Publishing

\section{Submit or recommend next manuscript to SCIRP and we will provide best} service for you:

Accepting pre-submission inquiries through Email, Facebook, LinkedIn, Twitter, etc. A wide selection of journals (inclusive of 9 subjects, more than 200 journals)

Providing 24-hour high-quality service

User-friendly online submission system

Fair and swift peer-review system

Efficient typesetting and proofreading procedure

Display of the result of downloads and visits, as well as the number of cited articles

Maximum dissemination of your research work

Submit your manuscript at: http://papersubmission.scirp.org/

Or contact jwarp@scirp.org 